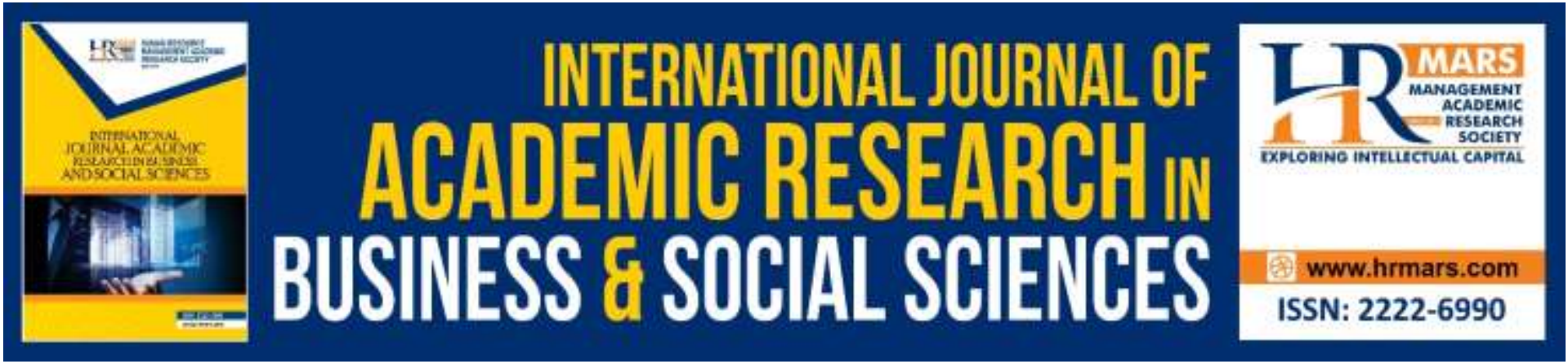

\title{
Improving Employment Opportunities in the Rural Areas through Cooperative Business Enterprises in Enugu State, Nigeria
}

\author{
P. C. Okonkwo, C. N. Onyeze, D. I. Ochiaka
}

To Link this Article: http://dx.doi.org/10.6007/IJARBSS/v9-i8/6348

DOI: $10.6007 /$ IJARBSS/v9-i8/6348

Received: 08 July 2019, Revised: 20 August 2019, Accepted: 02 September 2019

Published Online: 24 September 2019

In-Text Citation: (Okonkwo, Onyeze, Ochiaka, 2019)

To Cite this Article: Okonkwo, P. C., Onyeze, C. N., Ochiaka, D. I. (2019). Improving Employment Opportunities in The Rural Areas Through Cooperative Business Enterprises in Enugu State, Nigeria. International Journal of Academic Research in Business and Social Sciences, 9(8), 237-257.

Copyright: (C) 2019 The Author(s)

Published by Human Resource Management Academic Research Society (www.hrmars.com)

This article is published under the Creative Commons Attribution (CC BY 4.0) license. Anyone may reproduce, distribute, translate and create derivative works of this article (for both commercial and non-commercial purposes), subject to full attribution to the original publication and authors. The full terms of this license may be seen

at: http://creativecommons.org/licences/by/4.0/legalcode

Vol. 9, No. 8, 2019, Pg. 237- 257

http://hrmars.com/index.php/pages/detail/IJARBSS

JOURNAL HOMEPAGE

Full Terms \& Conditions of access and use can be found at

http://hrmars.com/index.php/pages/detail/publication-ethics 


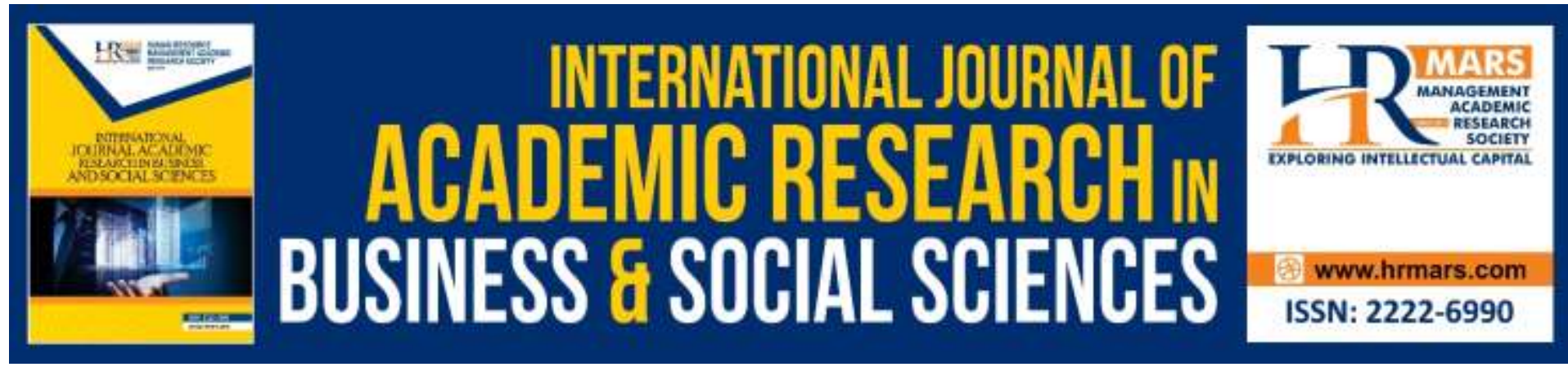

\title{
Improving Employment Opportunities in the Rural Areas through Cooperative Business Enterprises in Enugu State, Nigeria
}

\author{
P. C. Okonkwo, C. N. Onyeze, D. I. Ochiaka \\ Department of Co-operatives and Rural Development, Enugu State University of Science and \\ Technology
}

\begin{abstract}
The general aim of this research work is to examine "Improving Employment Opportunities in the Rural Areas through Cooperative Business Enterprise (A Study of Udi L.G.A of Enugu State)". The specific objectives of this research work include the following: to determine the number of cooperative societies business enterprises in Udi Local Government Area, to examine the role of cooperative business enterprise in reduction of unemployment in Udi Local Government of Enugu State. For a successful completion of this research work, the researcher made use of both primary and secondary methods of data collection for information gathering. The population of the study was 435 while the sample size of 208 was gotten through Taro Yamene formula. The data collected were presented in tables and analyzed with simple percentage while the hypotheses stated were tested with chi square. The findings made includes: the residents of Udi Local Government of Enugu State are aware of the existence of cooperative societies, the roles of cooperative business enterprise in reduction of unemployment in Udi Local Government of Enugu State are promoting self-employment, cooperatives induce wage employment, cooperatives promote capacity buildingand provision of educational and training facilities. In conclusion, the residents of Udi Local Government of Enugu State are aware of the existence of cooperative societies, the roles of cooperative business enterprise in reduction of unemployment in Udi Local Government of Enugu State are promoting self-employment, cooperatives induce wage employment, cooperatives promote capacity buildingand provision of educational and training facilities. The researcher therefore recommends that a business organization, cooperative societies in Udi Local Government of Enugu State needs proper funding, since they are finding it difficult to get their external sources of fund, the officers should try to keep proper book of account of the societies in order to avoid fraud and misappropriation of funds.
\end{abstract}

Keywords: Improving Employment, Rural Areas, Cooperative Business Enterprise 


\section{Introduction}

\section{Background of the Study}

Unemployment and poverty have become features of the living conditions and life situation of the vast majority of Nigerians. The incidence of unemployment and poverty in Nigeria was put at $28.8 \%$ in $1990,46.3 \%$ in $1995,42.7 \%$ in 2000 and $65.6 \%$ in 2005 . In 2008, estimates from the National Bureau of Statistics put incidence of poverty at $54.4 \%$ Ajakaiye and Olumola, (2010).

Poverty can be described as a multi-dimensional phenomenon, which lacks universally accepted definition C.B.N., (2009). For instance, its economic dimension centers on nature and level of material deprivations which afflict the poor, and distinguishes them from the nonpoor.

Chukwu, (2012) described poverty as a social problem whereby the household income is insufficient to ensure suitable livelihoods, consequently leading to hunger, malnutrition, ill health and mortality from illness while on the other hand, Okechukwu, (2007) defined unemployment as a situation where someone of working age is not able to get a job but would like to be in full time employment.

Brichall, (2010) stated that poverty is a state of involuntary deprivation to which a person, household, community or nation can be subjected. Poverty is a condition in which one cannot generate sufficient income required to secure a minimum standard of living in a sustainable pattern. This situation is attributed to a state of unemployment. Poverty in Nigeria is caused by lack of employment, high rate of illiteracy among the citizenry, poor infrastructure, inadequate access to micro credit facilities, mismanagement of public funds, bad governance, instability of the governments and its policies.

Fakoya and Ashimolowo, (2010) is of the view that unemployment and poverty give rise to many other serious social problems, some of which, not only impose enormous economic and social costs upon the non-poor and society in general, but also threaten the survival and stability of the society. In these regards, the Federal Government of Nigeria had designed several programs aimed at alleviating poverty and improving the living conditions of its people which include Operation Feed the Nation (OFN), Green Revolution, Structural Adjustment Program, Better Life Program and Family Support Program, National Directorate of Employment (NDE), Directorate of Food, Roads and Rural Infrastructure (DFRRI), National Poverty Eradication Pe (NAPEP) and National Economic Empowerment and Development Strategy (NEEDS). These program by the various governments of Nigeria were designed by policy makers and targeted at poverty alleviation in Nigeria. Unfortunately, the quality of life of majority of Nigerians had remained unenviable and embarrassingly low, despite the huge budgetary allocations by these governments to these poverty alleviation programm Ejeakanonu, (2007). There is a need to identify other means of addressing the serious damage caused by unemployment and poverty to the Nigerian society, attention should therefore be shifted to the use of self help using Co-operative organizations formed and administered by the people.

Co-operatives have been dedicated to conducting business in a way now being recommended as the most effective route to transformational development: putting people in charge of their own destinies and helping them bring services to their communities; increasing decision making, trust and accountability through democratic participation; providing a profitable connection to the private sector; building and protecting assets at the community level; limiting the role of government; and working together to resolve problems. 
A co-operative is an autonomous association of persons united voluntarily to meet their common economic, social, as well as cultural needs and aspirations through a jointly owned and democratically controlled enterprise

Epetimehin, (2006). A Co-operative is a group-based and member-owned business that can be formed for economic and social development in any sector Ajakaiye and Olumola, (2010). According to DFID (2005), cooperatives have four main characteristics:

$>$ First, they are formed by groups of people, who have a specified need or problem.

$>$ Secondly, the organization is formed freely by members after contributing to its assets.

$>$ Thirdly, the organization formed, is governed democratically in order to achieve desired objectives on equitable norms, and

$>$ Fourthly, it is an independent enterprise promoted, owned and controlled by people to meet their needs.

C.B.N (2009) assert that cooperatives provide self-employment through millions of workerowners of production and service cooperatives; financial cooperatives mobilize capital for productive investment and provide people with secure institutions for the deposit of savings; consumer cooperatives provide households with affordable goods and services reducing the proportion of income used for basic living costs, and similarly user-owned cooperatives such as housing, utility, health and social care cooperatives provide affordable access to basic services. It is based on this premise that this project in been designed to study cooperative as a means of promoting employment opportunities and poverty reduction in Nigeria.

\section{Statement of the Problem}

The unemployment and poverty situation in the society are at the increasing rate among the people due to the limitation of cooperatives awareness in the society. The people fail to know or understand what cooperative really means or its role in the society. Despite all the effort of unemployment and poverty alleviation by the cooperatives movement, there are obstacles that hinder people from participating and enjoying these economic developments. Such obstacles are: lack of adequate cooperative education or awareness and enlightenment amongst the populace as such people respond to cooperative movement very poorly. Those who are actively involved in this movement of the cooperatives do not also fully enjoy the economic aspect of the movement, which is the foremost objective of cooperative. This is because of the lack or inadequate cooperative knowledge of its members.

Also improper management by committee members of different cooperative societies have also affected their effort in reducing unemployment and as well as poverty reduction in Nigeria. Most cooperative societies do not hire the services of experts in diverse management positions and as a result, they have managers who either misappropriate their fund or inadequately control the affairs of the societies. This has led to the failure of many cooperative societies in Nigeria today.

\section{Objectives of the Study}

The broad objective of this study is to evaluate the impact of cooperatives in improving employment opportunities in the rural areas through cooperative business enterprise a case study of Udi Local Government Area.

The specific objectives include the following: 
1. To determine the number of cooperative societies business enterprises in Udi Local Government Area.

2. To examine the role of cooperative business enterprise in reduction of unemployment in Udi Local Government of Enugu State.

\section{Research Questions}

The following research questions are stated for this study:

1. What are the numbers of cooperative society's business enterprises in Udi Local Government Area?

2. What are the roles of cooperative business enterprise in reduction of unemployment in Udi Local Government of Enugu State?

\section{Research Hypotheses}

The following hypotheses are formulated for this study: HYPOTHESIS ONE

$\mathrm{H}_{\mathrm{o}}$ : The numbers of cooperative society's business enterprises in Udi Local Government Area is not significant.

$H_{1}$ : The numbers of cooperative society's business enterprises in Udi Local Government Area is significant.

\section{Hypothesis Two}

$\mathrm{H}_{0}$ : Cooperative business enterprises do not play significant roles in reduction of unemployment in Udi Local Government of Enugu State.

$\mathrm{H}_{1}$ : $\quad$ Cooperative business enterprises play significant roles in reduction of unemployment in Udi Local Government of Enugu State.

\section{Review of Related Literature \\ Conceptual Framework of the Study \\ Meaning of Cooperative Society}

Cooperative enterprises as self-help organizations play a significant role in uplifting the socio-economic conditions of their members and that of their local communities. Cooperative organizations operate as people centered businesses and also serve as catalysts for social organization and cohesion. The International Co-operative Alliance (ICA) which is apex organization that represents cooperatives worldwide defined a cooperative as: 'An autonomous association of persons united voluntarily to meet their common economic, social and cultural needs and aspirations through a jointly owned and democratically controlled enterprise' Nkamnebe and Nwankwo, (2007). This definition emphasizes that cooperatives are independent of governments and not owned by anyone other than their members themselves. They are associations of individuals which literally mean individual people but also 'legal persons', organizations that may themselves have members. Therefore federal bodies whose members are the primary cooperatives can also be cooperatives themselves and that small businesses can also be members of cooperatives. They are united voluntarily, and should be free to join or leave. This also means that collective farms or villages or neighbourhood associations that include all people in an area (whether or not they want to be members) are not genuine cooperatives (Ishola and Williamson, 2005). 
In general, the aim of cooperative formation is to offer an opportunity for local people to take development into their own hands and make it a meaningful concept at the local level (ljaiya and Bello, 2009). Cooperatives have arisen where the cost of adjustment to economic change has threatened to destroy communities and where local people needed power to control the pace and direction of change in order to preserve what they valued.

A conceptual model of cooperatives as a tool for unemployment and poverty reduction is presented in Figure 1.

Figure 1. Cooperatives as a tool for unemployment and poverty reduction

Cooperative organization

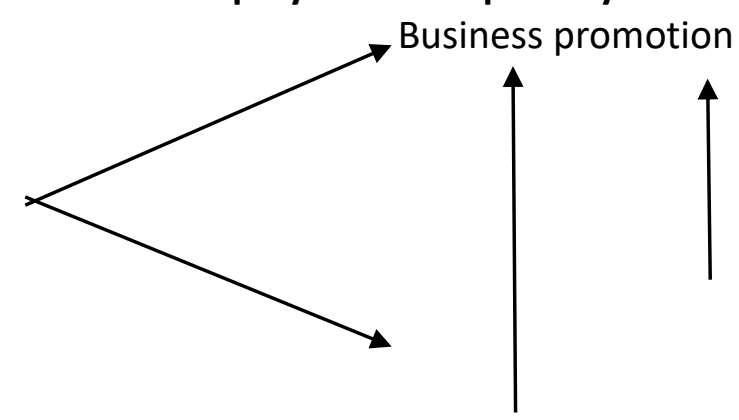

Unemployment and Poverty reduction

Intervening variables:

Human conditions

Social position

Enabling environment

Source: Ijere, (2003)

The cooperative organization works as the independent variable in the model and unemployment and poverty reduction and business promotion function as the dependent variables. The social positions, human conditions and the enabling environment are the intervening variables that influence the relationship of the dependent and independent variables.

Good management, good governance and human capital affect the performance of cooperatives. These factors are important in order to attract foreign capital.

In a developing country context, cooperatives and farmer groups have been studied by a number of scholars. In Nigeria the question as to whether smallholder farmer groups facilitate collective action initiatives to improve group marketing performance has been investigated by Izekor and Alufohai, (2010). Those authors basically found that even well-organized farmer groups will have little likelihood to succeed without a core of natural assets.

Lawal, (2006) found that farmers' associations (cooperatives) in Nigeria were able to increase farmers' profits per kilo of produce compared to traditional supply chains, by helping farmers to supply supermarkets directly with produce.

They concluded that farmer organizations had become major direct suppliers of supermarkets, unlike in traditional commodity chains where retailers are supplied by a chain of wholesalers and collectors that deal with farmers who sell on an individual basis. Farmers belonging to farmer groups received a better price from supermarkets than did single farmers for a number of reasons. The first was due to economies of scale in terms of the quantities collected (lower transaction costs, guaranteed delivery, lower cost of contracts). A second reason was the farmers groups enabled farmers to have training in terms of quality 
improvement. A third factor was the farmers group made joint investments in quality improvement, labeling and certification possible.

Todarro, (2007) is of the view that cooperatives are successful values-based businesses that are owned by their members. Whether they are customers, employees or residents, the members get an equal say in the business and a share of the profits. From the point of view of agricultural development, which is the economic foundation for national economic growth of most sub-Saharan countries, cooperatives are expected to serve a broad set of socio-economic and political objectives. These objectives range from self-help, grassroots participation, income distribution, exploitation of economies of scale, social control over resources to mobilization of rural population and increasing its productivity.

Ajakaiye and Olumola, (2010) stated that the benefits of forming cooperatives for entrepreneurs consist of positive economic effects for enterprises, for the individual member businesses and for the cooperative itself. Members of cooperatives can benefit from cooperation through economies of scale in production by selling products and buying inputs, through a greater opportunity for diversification by making the value chain longer and by the reduction of transaction costs. However, it has been shown that savings made in production costs themselves are not enough to justify the cooperation in entrepreneurs' cooperatives. Only when the benefits from lower production costs outweigh the increased organizational cost of the cooperatives will the entrepreneurial cooperative be successful.

It is therefore very important for the cooperative to quantify its coordination, organizational and production costs objectively since members can choose to leave the cooperative otherwise.

\section{The Concept of Unemployment}

Unemployment as defined by Todarro, (2007) "occurs when a person is available and willing to work but currently without work". Thus, Todarro agrees that only a person who is willing and available to work can be referred to as unemployed. This implies that not everybody who is not working is unemployed.

To Chukwu, (2012) unemployment occurs when people are looking for a job and cannot find one. This further concurs with the earlier definition where there is a conscious effort by the person or people seeking employment, but fails to point out if the person or people in question have something doing or not, because some people who are working seek new jobs. From the foregoing definitions, one is forced to ask if anybody willing and available to work could be termed unemployed, even if the person is a child. To this, Okechukwu, (2007) defined unemployment as "adults not holding a job but looking for one." Who then is an adult? An adult is one who is 18 years and above, therefore the definition could be said to be "Anyone who is 18 years and above who is not holding a job but looking for one could be termed unemployed.

In line with the aforementioned, the Bureau of Labour Statistics Brichall, (2010) considers a person who is 16 years or older who has not worked during the preceding week but made some effort to find work (for example, by going to a job interview) in the past four weeks as unemployed. The above requirements further limit the definition of unemployment and makes it only applicable to the western world, because in a third world country like Nigeria a person who is actively seeking for job may not be called for any interview in four weeks, does that then remove him/her from the category of the unemployed? 
On the other hand, the US census Bureau considers a person who actively looked for work in the preceding four weeks, who is not employed but actively seeking a job to be unemployed. This consideration is more universally accepted because it States that a person who has actively looked for job in the preceding four weeks and has not attended interviews.

Fakoya and Ashimolowo, (2010) defined unemployment using an illustration of a 37 years old man who has been doing very well at work enjoying bonuses and company-paid insurance and over night the company closed, thus forcing him to be on the streets looking for job in the next few weeks. This continued for about 2 years and eventually found a job that paid only half as much as his previous job. This illustration not only shows the meaning of unemployment but attempts to explain the pain, frustration of employment and joblessness.

To Ejeakanonu, (2007), unemployment refers to the State whereby able bodied, qualified men and women are available for and are willing to work but get no job to do. This definition is more elaborate because it dealt with specific requirements. The existence of a large number of people who do not have work and are looking for it is the most obvious evidence of unemployment could be referred to as visible unemployment.

Unemployment in Nigeria has actually become a menace, a vivid picture of which was painted by former executive secretary, National Manpower Board (NMB), Epetimehin, (2006) in The Guardian Newspaper of September 22, he said; the problem of unemployment amongst our tertiary graduates is of recent vintage, if situated in a historical perspective, it is not more than two decades since it started, but since then, it has become unabated and cumulative.

To him many young graduates move from long spells of unemployment to high crimes including armed robbery while others have become handy tools for unscrupulous politicians. The word unemployment connotes a situation in which persons who are actively seeking jobs are not able to secure them. Mustpaha in his work quoted Lawal, (2006) who argued that explaining unemployment in this way immediately throws up two problems of distinction. One is the distinction between joblessness and unemployment. To him, a jobless person may not necessarily be unemployed if he is not seeking job. Secondly, there is the distinction between seeking job and actively seeking a job because a "discouraged worker" or job seeker may be passively seeking job out of frustration from past search efforts. This is a good and important observation but either way, they are still without work and will be willing do one if they find.

To Epetimehin, (2006) open unemployment exists when there are people who are able to work, wishing to work, dependant on work for a livelihood but unable to obtain sustainable employment.

\section{Role of Cooperative Business Enterprise in Improving Employment Opportunities}

Cooperative could be the best way of tackling the perennial economic problems of a developing country like ours where a greater percentage of the people live below poverty level Fakoya and Ashimolowo, (2010). The group is purely service motivated to its members. Ejeakanonu, (2007) suggested that cooperation is necessary in all aspects of our social and economic life in order to improve our living standard. The Federal Government has found the cooperative movement a veritable tool for unemployment and poverty alleviation and rural development as manifested in the better life for rural development program and now in the family support programme with particular attention focused on the Family Economic Advancement Programme (FEAP) through which billions of naira are being injected into the 
rural economy. According to Epetimehin, (2006) people embrace accepted cooperation or cooperative way of life as a way of self help through mutual help that is, a way of helping oneself through the help of fellowmen working together.

Therefore various self help organization were formed by the people to help them solve their problems ranging from weeding of compounds, building of residential houses, planting and harvesting of crops and so on. Self-help group (SHG) is voluntary grass-root levels, self help group in the country include credit association, like cooperation societies, isusu group, age grade association, village rural development schemes Nkamnebe, and Nwankwo, (2007). They help to loans associations etc.

They help to alleviate the worst aspect of unemployment and poverty by mobilizing resources outside the government programs along with their own. The impact of this on productivity, and well being of members is noticeable, spearing from saving function credit function to development function.

Despite some obvious constraints of limited available funds, SHG's manifest a unique advantage over other bodies in the quest for poverty alleviation. This emanates from the closeness of the people, knowledge of the local conditions and responsiveness to group needs (Ishola and Williamson, 2005)

It is estimated that there are over 760 million individuals who have chosen the cooperative advantage values, ethics, principles and business competence (Todarro, 2007). This constitutes the cooperative advantage. Increasingly, they are embracing entrepreneurship in order to make their competitive enterprise. Therefore Ajakaiye and Olumola, (2010) suggested that cooperatives can contribute a great deal to unemployment and poverty alleviation both directly and indirectly. Cooperative societies help both members and employees to escape from unemployment and poverty or to protect those of them who may be facing the risk of unemployment and poverty. "Cooperative is not a philanthropic institution. It exists only to help its members and indirectly help the society in which it exist (C.B.N, 2009). In many countries, cooperatives are in the forefront in production and marketing of food stuffs, and consumer goods as well as financial insurance and social services.

Ejeakanonu (2007) is of the view that the concept of decent work and the notion that there should be economic growth with social equity resonate well with the cooperative model of economic and social organization. It has been argued that cooperatives are well placed to mobilize social capital and can therefore bridge the economic and the social by providing employment, an equitable distribution of profits and above all, social justice. Typically, cooperatives place more emphasis on job security for employee-members and employees' family members, pay competitive wages, promote additional income through profit-sharing, distribution of dividends and other benefits, and support community facilities such as health clinics and schools, than do private sector businesses, (Nkamnebe and Nwankwo, 2007). They also address issues of concern such as the environment and food security. The cooperative model, therefore, offers an important employment creation opportunity in the face of the global unemployment and underemployment problem prevalent in Nigeria.

Currently, it is estimated that the global cooperative movement directly provides productive self-employment for several hundred million worker-owners of production and services cooperatives, as well as the non-member employees of these and other cooperative enterprises. - Chukwu, (2012) noted that an increasing number of worker-owned cooperatives in Nigeria today provide employment to hundred of thousand of worker-owners 
in diverse sectors as health and social services, public services, education, transport, and tourism. Cooperatives are also major sources of employment in large-scale enterprises providing food stuffs, services to consumers, and financial services. Financial cooperatives provide people with secure institutions for the deposit of savings which also encourage the formation of new enterprises and thus create new jobs.

\section{The Factors that Hinder the Performance of Cooperatives in Unemployment and Poverty Alleviation}

In Nigeria, of five major types of the business organization, cooperatives seem to have fared least well in terms of overall performance ljaiya and Bello (2009). Their operation has been stalled by many problems and inherent limitations. The major ones are described below. 1. Management: For many cooperatives in Nigeria the story has been that of embezzlement, abuse of office by officers, fraudulent conversion of property to personal use. One of the impediments to poverty alleviation in the developing countries is the lack of internal motivation and ingenuity to fight poverty at the right time and in the right place. (ljere, 2003). 2. Inadequate Capitalization: Since cooperatives are inadequately funded, they cannot attract capable manpower. These adversely affect their performance.

According to Izekor and Alufohai, (2010), cooperatives were never intended to be business organization with profit-oriented objectives. He therefore opined that cooperative society may not carryout one activities of poverty alleviation perfectly due to insufficiency of capital. 3. Poor service condition of staff and members: This is when the staff and members are not working with good cooperative spirit and honest. "If you cannot co-exist with people, you can never make a good cooperator, and must also be prepared to display transparent honest when dealing with fellow cooperators and the society (Lawal, 2006).

4. Inadequate Infrastructures: Similarly, due to inadequate finance, many cooperatives cannot provide themselves with adequate transport, and storage facilities and also public utilities. A cooperative with inadequate infrastructures facility cannot alleviate poverty efficiently.

5. Lack of total commitment by members: Some members display high degree of apathetic attitude towards the affairs of the society.

6. Embezzlement: In many societies, the corrupted officials embezzle the fund mapped out for the activities.

\section{Theoretical Framework of the Study}

The theoretical framework of this study is focused on the Mancur Olson of collection action propounded by Arthur Bentley (2007). The theory shows that most organizations produce what the economist calls "public goods" - goods or services that are available to every member, whether or not he has borne any of the costs of providing them. Economists have long understood that defense, law and order were public goods that could not be marketed to individuals, and that taxation was necessary. They have not, however, taken account of the fact that private as well as governmental organizations produce public goods. The services the labor union provides for the worker it represents, or the benefits a lobby obtains for the group it represents, are public goods: they automatically go to every individual in the group, whether or not he helped bear the costs. It follows that, just as governments require compulsory taxation, many large private organizations require special and sometimes coercive devices to obtain the resources they need. 
This is not true of smaller organizations for, as this theory shows, small and large organizations support themselves in entirely different ways. The theory indicates that, though small groups can act to further their interest much more easily than large ones, they will tend to devote too few resources to the satisfaction of their common interests, and that there is a surprising tendency for the "lesser" members of the small group to exploit the "greater" members by making them bear a disproportionate share of the burden of any group action. This theory is applicable to this theory in that cooperative societies function as self help to members which invariably provide diversity of opportunities to members such as employment opportunities and poverty reduction.

\section{Empirical Review}

Ngene (2011) carried out a study on the Effectiveness of cooperative societies in eradication of poverty in Enugu State. His objectives were to investigate the role of cooperatives in eradicating poverty in Enugu State, to determine the challenges faced by cooperative societies in poverty eradication in Enugu State and to examine the measures adopted in circumventing such challenges. He adopted sample survey in his study and found out that cooperatives are well placed to mobilize social capital and can therefore bridge the economic and the social by providing employment, an equitable distribution of profits and above all, social justice. He also found out that cooperatives place more emphasis on job security for employee-members and employees' family members, pay competitive wages, promote additional income through profit-sharing, distribution of dividends and other benefits, and support community facilities such as health clinics and schools, than do private sector businesses. They also address issues of concern such as the environment and food security. The cooperative model, therefore, offers an important employment creation opportunity in the face of the global unemployment and underemployment problem prevalent in Nigeria.

C.B.N (2009) carried out a research on roles of cooperative societies in provision of credit facilities in Enugu state. His objectives were to investigate the role of cooperatives in provision of credit facilities for agricultural production in Enugu State, to determine the challenges faced by farmers in obtaining credit facilities from cooperative societies in Enugu State, to examine the efficiency of the management personnel hired by cooperatives in Enugu state and to examine how training and education of cooperatives' members affect their role in provision of credit facilities for agricultural production in Enugu State. He adopted regression analysis in this study and found out that cooperatives are medium through which services like provision of farm inputs, farm implements, farm mechanization, agricultural loans, agricultural extension, members' education, marketing of members farm produce and other economic activities and services are rendered to members. He also found out that it is the cooperative that embraces all type of farmers and a well organized and supportive cooperative is a pillar of strength for agriculture in Nigeria as they make available credit facilities for agricultural enterprises.

Uwachi (2011) studied the challenges and prospects of cooperative societies in poverty reduction. Her objectives were; to examine the role of cooperatives in poverty reduction in Enugu State, to identify the challenges militating against the role of cooperatives in poverty reduction and to recommend measures to overcome such problems. The study adopted sample survey for this study and found out that; co-operatives have been dedicated to conducting business in a way now being recommended as the most effective route to 
transformational development: putting people in charge of their own destinies and helping them bring services to their communities; increasing decision making, trust and accountability through democratic participation; providing a profitable connection to the private sector; building and protecting assets at the community level; limiting the role of government; and working together to resolve problems.

Muonaga (2008) on the other hand carried out a study on the effectiveness of cooperative societies in employment creation in Enugu State. His objectives were; to determine the role of cooperative societies in employment creation in Enugu State, to examine the extent to which cooperatives in Enugu state have created employment opportunities for the society and to indentify the role of government in promoting cooperatives' growth and development. He adopted ANOVA and Mean analysis for this study and found out that cooperatives provide self-employment through millions of worker-owners of production and service cooperatives; financial cooperatives mobilize capital for productive investment and provide people with secure institutions for the deposit of savings; consumer cooperatives provide households with affordable goods and services reducing the proportion of income used for basic living costs, and similarly user-owned cooperatives such as housing, utility, health and social care cooperatives provide affordable access to basic services.

\section{Methodology Research Design}

A research design is a systematic plan to study a scientific problem. The design of a study defines the study type (descriptive, correlational, semi-experimental, experimental, review, meta-analytic) and sub-type (e.g., descriptive-longitudinal case study), research question, hypotheses, independent and dependent variables, experimental design, and, if applicable, data collection methods and a statistical analysis plan (Orji, 2006). The researcher therefore adopted sample survey method for this study.

\section{Area of Study}

Udi local government is bounded by coordinates: $60191 \mathrm{~N} 70261 \mathrm{E}, 6.3170 \mathrm{~N} 7.4330 \mathrm{E}$. It is bounded on the North by Igbo etiti, on the South by Enugu North, on the east by Enugu east and on the west by Eziagu LGA all in Enugu state. Udi can be referred to as people leaving West of the coal city, Enugu state. The headquarter is in the city of Udi town.

The accessibility of Udi is easier because of the improved development and urbanization in the area. It is accessible by road, air and mobile communication. $9^{\text {th }}$ Mile corner in Udi serves as a junction or stopping place for the entire travelers coming to Enugu from the North, South and part of south east. The area has a good network: most of the roads are tarred while others are well graded.

\section{Composition and Population}

Udi Local Government Area has an area of about $897 \mathrm{~km}^{2}$ and Population of 234,002 at the 2006 census. From this local government four new development centres were created by Governor Chimaroke Nnamani Administration in the year 2003. These development centres include: Ezedike, Ojebeogene, Udi and Ugwunye local government development centres.

$>$ Ezedike local government development centre comprises of Akpakwume, Nze and Oghu 
$>$ Ojebe Ogene local government development centre comprises Awhum, Ebe, Abor, Ukana, Okpatu, Umulumgbe and Umuoka

$>$ Ugwunye local government development centre comprises of Amaozalla Affa, Egede, Affa, Amafia Affa and Amokwu Affa.

$>$ Udi local government development centre. It comprises Udi town, Obioma, Abia, Agbudu, Obinagu, Umuaga, Nachi, Oji Amokwe, Enugu Amokwe, Etiti Amokwe, Uwani Amokwe, Eke, Ngwo Asaa, Imeama Ngwo Assaa, Ameke Ngwo, Nsude Uboji Ngwo, Amankwo Ngwo.

\section{Political and Socio-Cultural Organizations}

It was discovered that before 1976 reform, that Udi like most communities in Igboland are republicans from time immemorial. They had no kings, and they had no organized military or police force. In fact, there have no formal judicial or penal system.

And it is on this condition that Ichie NOO Udala of Umuaga on June 19, 1973 stated that "Before the white man came we have no Chief that saw the affairs of the town. But we had several institutions that helped us organize our activities. The government of this town was not vested on man. In the olden days, each village had a person that we could now call a chief to head the town's political and administrative activities. This man was normally the oldest man of that village, and was called Onyisi ani. Within this village we have another man that heads the affairs of the "lineage" or Umunna called Okenye Umunna. During any case affecting the whole town, the ndi ishi ani, village heads would meet and discuss effectively the issues involved.

And so it was until a certain Udi man from Eke named Ozo Amulu Onwusi married a beautiful lady from Ebe named Chinazungwa ljeonyeabo. They had a son, Onyeama. He grew up to become the nearest Udi man having one identifiable ruler in living memory.

During the colonial period, Udi did not swallow colonialism hook, line, and sinker. Everyone, black or white could settle in Udi and co-exist constructively and peacefully. However, when the European tourists turned around to rule, the people refused the concept of taxation without representation.

Chief Onyeama n' Eke acquiesced to the tyrannical repudiation of popular participatory politics (Oha ne eze). The people revolted. So this spirit of revulsion at oppression was reenacted in the Udi Revolt and the bloody coal miner's strike (Iva valley, Enugu) on November 18, 1949 which signaled the beginning of the struggle for independence. It is no coincidence that Udi was the first political capital of lands east of the Nigeria. The capital was only moved to Enugu after the discovery of Coal in Udi Hills.

In the present day, Udi Local Government Area which involves democratic system of government, the head is the Chairman of the Local Government Area, Sole Administrator for Local Government Development Centre and Councilors down to traditional rulers.

Culturally, Udi has a certain commonality of culture, but it varies as much as cultural diversity in Igbo land. They include: Odo festival which occurs in northern parts of Udi (Odo ozo area), while Mmanwu appears more from Oshie to Neke communities. Eke is a town of both Odo and Mmanwu. Umuabi had the strongest attachment to the Mmanwu phenomenon; Nachi, much less so. Umuaga; besides its strong Mmanwu culture, has the popular rites of rebellion called "Okomoyo" during which the young are allowed to revel allnight long under the supposedly watchful eyes of the older folk. 
Moreover, other traditional practices include, marriage rites, New yam festival, Titletaking rites such as "Ichi Ozor". They believe in the sacredness of Ani, the earth deity, and in the supremacy of Chi ukwu (Almighty God). Each town in Udi has at least one major deity, a being force (alusi) to which a shrine is built. In the table below are some towns in Udi Local Government Area and their various deities:

\begin{tabular}{|l|l|}
\hline \multicolumn{1}{|c|}{ Town } & Major Deity (alusi) \\
\hline Udi & Ani Udi \\
Umuaga & Nneche Umuaga \\
Abia, Amaokwe and Udi town & Aniobodoishiokwe \\
Abia & Onu Eke Oga \\
Okpatu & Affia \\
Awhum & Ukwuakpu \\
Umulumgbe & Ugwuedem \\
Affa & Dinapata \\
\hline
\end{tabular}

When the white men came, they came with their religion and their method of Education. The towns in Udi local government areas embraced both their education and their religion. The Udi north are predominantly of Roman Catholic denomination while the Southern Udi embraced CMS (Anglican Church).

It was the politic in religion that made it that Onyeama a paramount Chief within the Udi enclave did not allow the Church Missionary Society to penetrate more into Agbaja area where he controlled. Even though he openly desired no part of Christianity, he invited and encouraged church missionaries - to teach his people the ways of the white man. When the CMS would not teach English, but in Owere dialect of the Igbo language, Onyeama expelled them and brought in the Roman Catholics, on the condition that they teach in English and Latin and let his people speak their own dialect of Igbo! From his kingdom, the Catholic Church reached all parts of northern Igboland, Ogoja and Benue areas. He encouraged serious economic development, including mineral exploration and railway construction linking Enugu with Port Harcourt. This Kingdom stretched even down to Nsukka areas of which most of the towns have more of Roman Catholic Churches than CMS. Through the establishment of their religion they also introduced their education which enabled people to interact with them. The churches so far established helped to curb some of the devilish habits of the people. As they embraced these big religious bodies they also allow the existence of other churches. In fact they are not inclined only to traditional religion they practice Christianity to the core.

The motives of their education were to prepare ground for the exploitation of the hinterland so that their language could be interpreted as to enable them get what they wanted. The Udi people gained exceedingly from them as they not only interpreted but they delved into other field of human endeavour. The first Igbo medical doctor was Dr Simon Ezevuo Onwu, son of Ozo Offianaecheafa of Amaozalla Affa. The first Nigerian World Court Judge Justice Charles Dadi Onyeama, a contemporary of Dr Onwu was also an Udi son from Eke.

There were a lot of prominent men in Udi that shone like bright star among whom were Justice Philip Nnaemeka Agu and Anthony Aniagolu, Chief Gabriel Onoh the father of Chief C.C. Onoh. There are Professors like Odenigwe, Egudu, Aneke, Chime, Nebo and others that 
could not be included in this write up. There were also great teachers, technocrats and technicians that had contributed immensely to the welfare of the Local government and Nigeria at large.

Under this political dispensation the son of Udi, His Excellency, Bar. Sullivan Iheanacho Chime is the governor of Enugu State. Other intelligent and well educated ones occupied other positions in Enugu State and they are men from Udi enclave.

It is important to note that, no Udi town speaks exactly the same dialect as the other. It is obvious to detect the differences. The different towns that made up Udi local government have different taboos. For example, the people of Umuaga do not eat snails, in Ngwo, Afia usu market is located beneath giant cotton tree on which bats habit in their thousands. Though eating bat is not prohibited, no one would be allowed to kill any of the bats at the giant cotton tree. Oshie communities curiously do not inter marry, for they are descended from one man; curious because intra-marriage occurs in these communities. Intermarriage is virtually zero between that people of Nsude, Eke, Amaokwe, Abia and Udi.

\section{Occupation and Source of Revenue of the Area}

The occupation of the inhabitants of Udi Local Government Area is predominantly agriculture. They involve in agricultural activities such as cultivation of cassava, yams, cashew trees, stringed beans, vegetables, oil beans, tropic fruits and assorted agricultural products.

Some population embarks on trading since there are areas like $9^{\text {th }}$ Mile Corner which is a booming place for business. For those who want natural drinks, the best palm wine in the whole wide world "Aneke Achime" flow from Nkwo Agu market in abundance to compliment the best "Okpa" (Udi bread) on earth. So Udi is said to produce the best palm wine.

The land near or close to $9^{\text {th }}$ Mile Corner is blessed with a natural aquifer which is very close to the surface of the earth. So the area serves as a good source of pipe borne water which is used in all part of Enugu State and even beyond. Also because of this aquifer, the largest brewery in West Africa (Amah brewery) and the major bottling companies ranging from Coca-Cola bottling Company Plc, Limca and Seven Up to create employment to the people of Udi Local Government Area and generate revenue for the Udi Local Government Area. (www.enuguhistory.ng.gov)

\section{Source of Data}

The data used for this study were obtained from two main sources as follows:

Primary Sources: This is an original way of gathering information. It is made up questionnaire and oral interviews.

Secondary Source: Secondary source of information are those which contain accounts of events or phenomena by other people who did not participate or witness the events. They are Textbooks, Journals and Periodical, Newspapers, Magazines etc.

\section{Population of the Study}

There are a total of 148 registered and functional cooperative societies in Udi Local Government Area but the population of study covers five selected cooperative societies in Udi Local Government Area. They include the following: 
i. Udi Fadama Community Association Cooperative Society Limited

ii. Ikedioramma Okpatu Cocoyam Fadama Users Co-Operative Society

iii. Udemba cooperative society, Umulumgbe

iv. Uwanyimba multi-purpose cooperative society, Amaokwe

v. Anayochukwu Agro Marketing cooperative Ltd, Okpata

vi. Adogba Multipurpose cooperative society, Achi

vii. Azieha cooperative society

viii. Ogbueze women Multipurpose cooperative society

ix. Future Hope Agro-Marketing Coop. Society Ltd

x. Anayochukwu Agro-Marketing Co-op. Limited

The selection of ten cooperatives out of the 148 existing cooperatives in the local government was based on active participation of the cooperatives to societal development of the local government.

The distribution of the population is shown below:

Table 1 Population Distribution

\begin{tabular}{|l|l|}
\hline Respondents & No of members \\
\hline $\begin{array}{l}\text { Udi Fadama Community Association Cooperative Society Limited } \\
\text { Ikedioramma Okpatu Cocoyam Fadama Users Co-Operative }\end{array}$ & 60 \\
\hline Society & 51 \\
\hline Udemba cooperative society, Umulumgbe & 66 \\
\hline Uwanyimbamulti-purpose cooperative society, Amaokwe & 78 \\
\hline Anayochukwu Agro Marketing cooperative Ltd, Okpata & 46 \\
\hline Adogba Multipurpose cooperative society, Achi & 30 \\
\hline Azieha cooperative society & 26 \\
\hline Ogbueze women Multipurpose cooperative society & 29 \\
\hline Future Hope Agro-Marketing Coop. Society Ltd & 34 \\
\hline Anayochukwu Agro-Marketing Co-op. Limited & 15 \\
\hline Total & 435 \\
\hline
\end{tabular}

Source: Field Survey, 2018

\section{Determination of Sample Size}

In order to get a representation of the entire population, the Taro Yamani statistical formula was employed. According to Taro Yamene (1964) the formula is stated as follows $\mathrm{n}=\frac{\mathrm{N}}{1+\mathrm{N}(\mathrm{e})^{2}}$

Where $\mathrm{n} \quad=$ represents the sample size

$\mathrm{N} \quad=$ represents the population

e $\quad=$ represents the margin of error

I = constant

For the purpose of this study, $\mathrm{N}$ will be equal to 435 , e will be assumed to be $5 \%$ Therefore the sample size for this research work will be $n=\frac{435}{1+435(0.05)^{2}}$ 


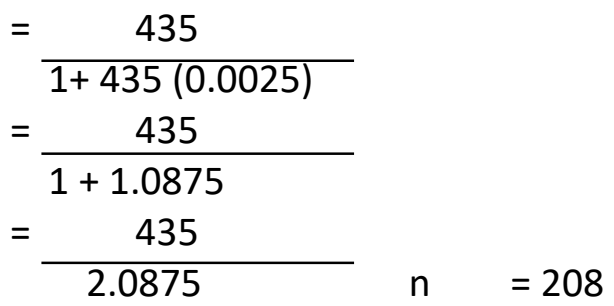

The sample size for this study is 208 cooperative members.

\section{Research Instrument}

The research instrument that was used by the researcher in collecting useful information on this topic is questionnaire.

In this study, the questionnaire used by the researcher was highly structured and it contains close ended questions to elicit relevant reactions from their respondents.

It was also carefully designed to accommodate two sections. The first section is personnel data which will generate proper data regarding to the respondents characteristics like; sex, age, educational level while the other deals on relevant aspects of the topic under study.

\section{Sampling Techniques}

In order to get a good representation of the population, the researcher used stratified random sampling techniques. To make a sample a true representation of the parent population, he first divided the entire population into homogenous groups called strata. By applying the systematic sampling, he selected items from each stratum into the sampling. Using this method, she selected items out of a population of the respondents.

\section{Method of Data Analysis}

In treating and analyzing of data collected extensive use of tabular and percentage will be paramount. The data collected will be presented in table and analyzed with percentage. The hypotheses will be analyzed by the use of Chi - Square formular. The formular is shown below:

$$
\begin{array}{ll}
\mathrm{X}^{2}=\Sigma(\mathrm{o}-\mathrm{e})^{2} \\
\text { Where: } & \mathrm{e} \\
& \mathrm{X}^{2}=\text { Chi }- \text { Square } \\
& \mathrm{O}=\text { Observed frequency } \\
\mathrm{E}=\text { Expected frequency }
\end{array}
$$

\section{Test of Hypotheses}

The hypotheses will be tested using the chi-square formula stated below:

$$
\mathrm{X}^{2}=\frac{\sum(0-\mathrm{E})^{2}}{\mathrm{E}}
$$

Where:

$\begin{array}{lll}\mathrm{X}^{2} & = & \text { calculated chi-square } \\ 0 & = & \text { observed frequency } \\ \mathrm{E} & = & \text { expected frequency } \\ \Sigma & = & \text { summation }\end{array}$


The expected frequency $(E)$ is calculated by adding all the observed frequency $(0)$ and dividing by the number of observations.

Decision Rule: If the calculated chi-square value $\left(\mathrm{X}^{2}\right)$ is greater than or equal to the table value at 0.05 level of significance, the alternate hypothesis $\left(\mathrm{H}_{1}\right)$ is accepted, but if the calculated chi-square value is less than the table value, the null hypothesis $\left(H_{0}\right)$ is accepted.

\section{Test of Hypothesis One}

$\mathrm{H}_{0}$ : The numbers of cooperative society's business enterprises in Udi Local Government Area is not significant.

$H_{1}$ : The numbers of cooperative society's business enterprises in Udi Local Government Area is significant.

Table 2 was used to test the hypothesis

\begin{tabular}{|l|l|l|l|l|l|}
\hline Variables & $\mathbf{O}$ & $\mathbf{E}$ & $\mathbf{0 - E}$ & $(\mathbf{O}-\mathbf{E})^{\mathbf{2}}$ & $\frac{(\mathbf{O}-\mathbf{E})^{\mathbf{2}}}{\mathbf{E}}$ \\
\hline Strongly agree & 79 & 48.75 & 30.25 & 915.06 & 18.77 \\
\hline Agree & 55 & 48.75 & 6.25 & 39.06 & 0.80 \\
\hline Disagree & 32 & 48.75 & -16.75 & 280.56 & 5.76 \\
\hline Strongly disagree & 29 & 48.75 & -19.75 & 390.06 & 8 \\
\hline Total & $\mathbf{1 9 5}$ & $\mathbf{1 9 5}$ & & & $\mathbf{3 3 . 3 3}$ \\
\hline
\end{tabular}

The calculated chi-square value $=33.33$

$\mathrm{Df}=(\mathrm{C}-1)(\mathrm{R}-1)=(2-1)(4-1)=3$

Table value at 0.05 of significance and 3 degree of freedom (Df) $=7.3777$

Decision: Since the calculated chi-square $\left(X^{2}\right)$ value (33.33) is greater than table value (7.3777), we reject the null hypothesis $(\mathrm{Ho})$ and accept the alternate hypothesis $\left(\mathrm{H}_{1}\right)$. Therefore, the numbers of cooperative society's business enterprises in Udi Local Government Area is significant.

\section{Test of Hypothesis Two}

$\mathrm{H}_{0}$ : Cooperative business enterprises do not play significant roles in reduction of unemployment in Udi Local Government of Enugu State.

$\mathrm{H}_{1}$ : $\quad$ Cooperative business enterprises play significant roles in reduction of unemployment in Udi Local Government of Enugu State.

Table 3 was used to test the hypothesis

\begin{tabular}{|l|l|l|l|l|l|}
\hline Variables & $\mathbf{O}$ & $\mathbf{E}$ & $\mathbf{0}-\mathbf{E}$ & $(\mathbf{O}-\mathbf{E})^{\mathbf{2}}$ & $\frac{(\mathbf{O}-\mathrm{E})^{\mathbf{2}}}{\mathbf{E}}$ \\
\hline Strongly agree & 71 & 48.75 & 22.25 & 495.06 & 10.16 \\
\hline Agree & 60 & 48.75 & 11.25 & 126.56 & 2.60 \\
\hline Disagree & 37 & 48.75 & -11.75 & 138.06 & 2.83 \\
\hline Strongly disagree & 27 & 48.75 & -21.75 & 473.06 & 9.70 \\
\hline Total & $\mathbf{1 9 5}$ & $\mathbf{1 9 5}$ & & & $\mathbf{2 5 . 2 9}$ \\
\hline
\end{tabular}

The calculated chi-square value $=25.29$ 
$\mathrm{Df}=(\mathrm{C}-1)(\mathrm{R}-1)=(2-1)(4-1)=3$

Table value at 0.05 of significance and 3 degree of freedom (Df) $=7.3777$

Decision: Since the calculated chi-square $\left(X^{2}\right)$ value $(25.29)$ is greater than table value (7.3777), we reject the null hypothesis $(\mathrm{Ho})$ and accept the alternate hypothesis $\left(\mathrm{H}_{1}\right)$. Therefore, Cooperative business enterprises play significant roles in reduction of unemployment in Udi Local Government of Enugu State.

\section{Discussion of Findings}

The study found out that the numbers of cooperative society's business enterprises in Udi Local Government Area is significant. This assertion is based on the premise that calculated chi square of this response which was 33.33 was greater than the tabulated chi square of 7.377. Therefore, the alternative response was accepted while the null was rejected implying that the numbers of cooperative society's business enterprises in Udi Local Government Area is significant. This is in view of the assertion of Ejeakanonu (2007)who stated that the knowledge and awareness of cooperatives' existence provide selfemployment through millions of worker-owners of production and service cooperatives; financial cooperatives mobilize capital for productive investment and provide people with secure institutions for the deposit of savings; consumer cooperatives provide households with affordable goods and services reducing the proportion of income used for basic living costs, and similarly user-owned cooperatives such as housing, utility, health and social care cooperatives provide affordable access to basic services.

The researcher found out that cooperative business enterprises play significant roles in reduction of unemployment in Udi Local Government of Enugu State. This is because the calculated chi square of the response which was 25.29 was greater than the tabulated chi square which was 7.377. Therefore, the alternative hypothesis was accepted while the null hypothesis was rejected implying that Cooperative business enterprises play significant roles in reduction of unemployment in Udi Local Government of Enugu State. This is in view of Ajakaiye and Olumola, (2010) as they suggested that cooperatives can contribute a great deal to unemployment and poverty alleviation both directly and indirectly. They assert that cooperative societies help both members and employees to escape from unemployment and poverty or to protect those of them who may be facing the risk of unemployment and poverty.

\section{Summary of Findings}

The summary of findings made for this study includes the following:

1. The study discovered that $62 \%$ of the respondents are of the opinion that the residents of Udi Local Government of Enugu State are aware of the existence of cooperative societies while $38 \%$ of them said no to this. Therefore, the residents of Udi Local Government of Enugu State are aware of the existence of cooperative societies.

2. The study found out that $41 \%$ of the respondents are of the view that the total numbers of cooperative society's business enterprises in Udi Local Government Area are $148,28 \%$ said $140,16 \%$ said 135 while $15 \%$ said 153 . Therefore, the total numbers of cooperative society's business enterprises in Udi Local Government Area are 148.

3. The researcher found out that $31 \%$ of the respondents are of the view that one 
of the roles of cooperative business enterprise in reduction of unemployment in Udi Local Government of Enugu State is promoting self-employment, 31\% said cooperatives induce wage employment, $19 \%$ said cooperatives promote capacity building while $14 \%$ said provision of educational and training facilities. Therefore, the roles of cooperative business enterprise in reduction of unemployment in Udi Local Government of Enugu State are promoting self-employment, cooperatives induce wage employment, and cooperatives promote capacity buildingand provision of educational and training facilities.

\section{Conclusion}

The study concludes thus;

1. The residents of Udi Local Government of Enugu State are aware of the existence of cooperative societies.

The total numbers of cooperative society's business enterprises in Udi Local Government Area are 148.

2. The roles of cooperative business enterprise in reduction of unemployment in Udi Local Government of Enugu State are promoting self-employment, cooperatives induce wage employment, cooperative promote capacity buildingand provision of educational and training facilities.Cooperative management affects its growth and development.

3. The challenges militating against the roles of cooperative business enterprises in reduction of unemployment in Udi Local Government of Enugu State are inadequate Capitalization, poor service condition of staff and members, inadequate Infrastructuresand poor cooperative management.

4. The measures adopted by cooperative business enterprise in Udi Local Government of Enugu State in ameliorating these challenges are easy access to fund, easy access to market facilities, improvement in infrastructural developmentand improved cooperative management.

\section{Recommendations}

The following recommendations are made for this study:

1. The officers of the cooperative societies in Udi Local Government of Enugu State should be made up of cooperators who are highly knowledgeable, honest, hardworking and selfless. They should be able to motivate the members and direct activities towards achieving set objectives.

2. As a business organization, cooperative societies in Udi Local Government of Enugu State needs proper funding, since they are finding it difficult to get their external sources of fund.

3. The officers should try to keep proper book of account of the societies in order to avoid fraud and misappropriation of funds.

4. Persons who join cooperative societies in Udi Local Government of Enugu State must be prepared to do work with others to achieve the societies set objectives and must also be prepared to display transparent honesty when dealing with fellow cooperative and societies.

\section{References}

Ajakaiye, D. O. and Olumola, S. A. (2010). Conceptual and Methodological Issues in Poverty Alleviation, Lagos: Mushino and Sons Publications. 
Arthur, B. (2007) Cooperative Theory. New York: McGraw Hill Inc

C. B. N. (2009). "Nigeria Development Prospect: Poverty Assessment and Alleviation Study, Research Department Central Bank of Nigeria. Vol. 4 (2).

Central Bank of Nigeria (2009). "Nigeria Development Prospect: Poverty Assessment and Alleviation Study, Research Department Central Bank of Nigeria. Vol. 4 (2).

Chukwu, S. C. (2012). "The Economic and Management of the cooperative Business Enterprise" Enugu: Johnbest Publishing Company.

Brichall, J. (2010). Rediscovering the Co-operative Advantage: Poverty Reduction through Selfhelp. New York: McGraw Hill Inc.

Ejeakanonu, E. C. O. (2007) The role of cooperative towards economic development of Anambra State: A case study of Ihiala L. G. A. Unpublished BSc Thesis, Awka: Department of Co-Operative Economics and Management, Nnamdi Azikiwe University.

Epetimehin, F. M. (2006). Understanding the Dynamics of Cooperatives. Ibadan: Tadon Publishers.

Fakoya, E. O., and Ashimolowo, O. R. (2010). "Cassava production and poverty eradication among crop farmers in Ondo State, Nigeria". International Journal of Sustainable Development, Vol. 2(5).

Ishola, S. and Williamson, I. (2005). The Cooperative Movement in Nigeria. Onitsha: African Fep Publishers.

ljaiya, M. A., and Bello, A. T. (2009). "Agricultural credit guarantee scheme and food security in Nigeria". Journal of International Economic Review Vol. 22 (1-2).

ljere, M. O. (2003). "The Prospect of employment creation through Cooperatives in Nigeria". Nigeria Journal of Rural Development and Cooperative studies, Vol. 17(7).

Izekor, O. B., and Alufohai, G. O. (2010). "Assessment of cooperative societies effectiveness in agricultural credit delivery". African Journal of General Agriculture Vol. 6(3)

Lawal, T. O. (2006) Introduction to Modern Cooperative Management. Akure: Alibi -Eyo and Co Ltd.

Muonaga, H. (2008) The Effectiveness of Cooperative Societies in Employment Creation in Enugu State. Enugu: Munthy Publications.

Ngene, E. (2011) The Effectiveness of Cooperative Societies in Eradication of Poverty in Enugu State. Enugu: ABIC Books and Equipment.

Nkamnebe, A. D., and Nwankwo, F. (2007) Capacity Building in Management and Entrepreneurship for Sustainable Development. Lagos: Rex Charles and Patrick Publishers.

Okechukwu, E. (2007). Cooperative Business: Principles and Practice, Onitsha: Hybrid Publishers Limited.

Todarro, M. P. (2007). Introduction to Community Development: The Role of Cooperatives. New Jersey: Opuntia Press.

Uwachi, T. (2011) The Challenges and Prospects of Cooperative Societies in PovertyReduction. Enugu: New Generation Books. 